SALVADOR (José Gonçalves). - Cristãos-Novos, Iesuítas e Inçuisisi̧ão. Biblioteca Pioneira de Estudos Brasileiros. Editôra da Universidade de São Paulo. 1969. 222 páginas.

Esta obra é dedicada mais aos históriadores e especialistas em sociologia, isto porque, nela encontramos figuras de destaque de nossa história envolvidas no processo inquisitorial.

Como o próprio título indica, trata-se de um estudo sôbre os cristãos-novos, jesuitas e Inquisição no Brasil, tendo como destaque as capitanias do sul, no período compreendido entre 1530 e 1630 .

Se algumas obras foram escritas quanto a presença de cristãos-novos no Brasil, estas se detiveram em analisar as capitanias do norte, onde a documentação é mais abundante.

Nêste livro, procura 0 autor mostrar a influência dos mesmos nas regiōes sulinas.

A primeira parte do livro compōe-se de um estudo dos cristãos-novos e seu ingresso nas ordens religiosas.

Para tanto procura, na introdução, caracterizar a situação dos judeus. Faz um retrospecto histórico dêste povo, sua instalação na Europa e principalmente na Peninsula Ibérica.

Com o estabelecimento do Santo Ofício, mostra as dificuldades passadas, as artimanhas realizadas para compra de títulos, a comprovação da "limpeza de sangue", assim como as perseguiçōes sofridas e os castigos impostos.

0 professor Salvador não se preocupa em mostrar o porquê da Inquisição, ou qual o papel importante exercido por ela na sociedade.

Todo o livro é baseado em pesquisas, com um documentário de grande importância.

Quando encontramos uma afirmação como, por exemplo, dos altos cargos ocupados pelos judeus, quer nas ordens religiosas quer como pessoas influentes dos reinos, procura o autor dar além dos personagens, a sua origem, isto é, sua árvore genealógica. Elimina, desta forma, qualquer traço de dúvidas.

Quanto às ordens religiosas há necessidade de destacar a Companhia de Jesus, fundada por Inácio de Loyola, o qual era descendente de família judaica (p. 126).

Permitiu a Ordem levá-los a um entendimento com a doutrina cristã, onde de certa forma procurou catequisá-los. Em poucos anos consegui am altos postos, chegando mesmo a posiçōes de alto nível.

A rivalidade com a ordem dos Dominicanos é um campo vasto para as pesquisas. Estes diziam jocosamente que os nobres buscavam cs dcminicanos enquanto os judeus os jesuitas.

No capítulo IV trata dêste assunto, dando uma idéia nítida do número elevado de cristãos-novos na Companhia de Jesus.

No Brasil encontramos no grupo pioneiro de jesuitas, José de Anchieta, que carregava em suas veias uma parcela de sangue judeu, conforme pesquisa elabo.ada (p. 140).

Vários nomes são citados, famílias como a dos: Coutinho, Vale, Mendes da Silva, Caldeira Ximenes, Gomes da Costa, Rodrigues e uma série de outras que aparecem no decorrer da obra. 
O Autor apresenta uma documentação farta, com fontes manuscritas; impressas, bibliografia, índice onomástico, facilitando desta forma as pesquisas futuras.

E' um trabalho que carece, talvez, de maior meditação e de interpretação, pois nos pareceu sempre mais voltado para a simples descrição. Isto não quer dizer que o Autor não tenha dado excelente contribuição ao estudo das ordens religiosas e do papel do elemento judeu na vida brasileira.

E', enfim, a obra de interêsse para todo estudioso do período.

\section{EDNA RODRIGUES OKAY}

MACHIAVEL (Nicolas). - o Príncipe. Editôra Civilização Brasileira. Rio de Janeiro. 1969. Trađução de Roberto Grassi.

Publicado em 1532, desde então se tornou $O$ Principe (ou melhor, Do Principado), de Maquiavel, um dos livros mais famosos e contravertidos do mundo. E que, esteando-se em observaçōes hauridas na experiência contemporânea e no estudo da história, em contraposição com os tratadistas que se arrimavam na ética racional e nas Escrituras Santas, $O$ Principe representou, na política da época, revolução idêntica à que, um século mais tarde, operaria, na filosofia, o Discurso do Método, de Descartes. Assim como êste sacudiu o jugo da autoridade escolástica, fazendo da observação a base do conhecimento científico e filosófico, $O$ Principe desprendeu as normas políticas das concepçōes teológicas, vindas da Idade Média, para transformá-las em simples frutos da observação direta e qüotidiana, considerando a arte de governar sob prisma exclusivamente objetivo e realístico. Foi o que Bacon salientou ao frisar que Maquiavel se limitou a registrar, no Principe, o que os soberanos faziam e não o que deveriam fazer. Depois de haver sido indutiva com Aristóteles, passara a política, da Idade Média, a ser fantasista, entregando-se à construção de meros entes de razão, sem raízes no mundo real, de acôrdo com o exemplo de Platão em sua República. Maquiavel reagiu contra êsse predomínio da imaginação sôbre a observação.

Assim como Leonardo Da Vinci praticava, em seu tempo, as ciências experimentais, avaliando-lhes o poder e prevendo-lhes o portentoso futuro, Maquiavel praticou, em política, verdadeiro positivismo científico, ao baseá-la na experiência e na observação. Ligando a causas puramente naturais a explicação dos acontecimentos políticos, tornou-se um precursor de Montesquieu ao ver nêles a resultante das relações necessárias que a natureza das coisas estabelece entre os homens. E também precedeu a Augusto Comte na fundação de uma ciência que está, para os fatos políticos, como a fisíca para os fenômenos naturais.

Afastando de suas cogitações qualquer concepção teológica acêrca do homem e da sociedade, Maquiavel introduz o método positivo na apreciação das realidades sociais. Estuda o aparecimento das formas políticas, as causas internas e externas de sua decadência e procura desvendar as leis que, através do mundo antigo e moderno, thes determinam o nascimento e o declínio. Erro freqüente é supor-se 